\title{
Large-Scale Production of Bioactive Terrein by Aspergillus terreus Strain S020 Isolated from the Saudi Coast of the Red Sea
}

\author{
Hani Z. Asfour ${ }^{1}$, Zuhier A. Awan ${ }^{2}$, Alaa A. Bagalagel ${ }^{3}$, Mahmoud A. Elfaky ${ }^{4} \oplus$, \\ Reda F. A. Abdelhameed ${ }^{5}$ and Sameh S. Elhady $4,6, * \mathbb{D}$ \\ 1 Department of Medical Microbiology and Parasitology, Faculty of Medicine, Princess Al-Jawhara Center of \\ Excellence in Research of Hereditary Disorders, King Abdulaziz University, Jeddah 21589, Saudi Arabia; \\ hasfour@kau.edu.sa \\ 2 Department of Clinical Biochemistry, Faculty of Medicine, King Abdulaziz University, \\ Jeddah 21589, Saudi Arabia; zawan@kau.edu.sa \\ 3 Department of Clinical Pharmacy, Faculty of Pharmacy, King Abdulaziz University, \\ Jeddah 21589, Saudi Arabia; abagalagel@kau.edu.sa \\ 4 Department of Natural Products and Alternative Medicine, Faculty of Pharmacy, King Abdulaziz University, \\ Jeddah 21589, Saudi Arabia; melfaky@kau.edu.sa \\ 5 Department of Pharmacognosy, Faculty of Pharmacy, Suez Canal University, Ismailia 41522, Egypt; \\ omarreda_70@yahoo.com \\ 6 Department of Pharmacognosy, Faculty of Pharmacy, Port Said University, Port Said 42526, Egypt \\ * Correspondence: ssahmed@kau.edu.sa; Tel.: +966-544-512-552; Fax: +966-269-516-96
}

Received: 20 August 2019; Accepted: 9 September 2019; Published: 12 September 2019

\begin{abstract}
The diversity of symbiotic fungi derived from two marine sponges and sediment collected off Obhur, Jeddah (Saudi Arabia), was investigated in the current study. A total of 23 isolates were purified using a culture-dependent approach. Using the morphological properties combined with internal transcribed spacer-rDNA (ITS-rDNA) sequences, 23 fungal strains (in the majority Penicillium and Aspergillus) were identified from these samples. The biological screening (cytotoxic and antimicrobial activities) of small-scale cultures of these fungi yielded several target fungal strains which produced bioactive secondary metabolites. Amongst these isolates, the crude extract of Aspergillus terreus strain S020, which was cultured in fermentation static broth, 21 L, for 40 days at room temperature on potato dextrose broth, displayed strong antimicrobial activities against Pseudomonas aeruginosa and Staphylococcus aureus and significant antiproliferative effects on human carcinoma cells. Chromatographic separation of the crude extract by silica gel column chromatography indicated that the S020 isolate could produce a series of chemical compounds. Among these, pure crystalline terrein was separated with a high yield of $537.26 \pm 23.42 \mathrm{~g} / \mathrm{kg}$ extract, which represents the highest fermentation production of terrein to date. Its chemical structure was elucidated on the basis of high-resolution electrospray ionization mass spectrometry (HRESIMS) or high-resolution mass spectrometry (HRMS), 1D, and 2D NMR spectroscopic analyses and by comparison with reported data. The compound showed strong cytotoxic activity against colorectal carcinoma cells (HCT-116) and hepatocellular carcinoma cells (HepG2), with $\mathrm{IC}_{50}$ values of 12.13 and $22.53 \mu \mathrm{M}$, respectively. Our study highlights the potential of $A$. terreus strain S020 for the industrial production of bioactive terrein on a large scale and the importance of future investigations of these strains to identify the bioactive leads in these fungal extracts.
\end{abstract}

Keywords: Red Sea; sponges; deep sediment; phylogenetic diversity; Aspergillus terreus; terrein; cytotoxic; antimicrobial 


\section{Introduction}

The marine habitat is an attractive source of both biological and chemical diversity. It has been reported that oceans contain nearly 291,000 described species, representing only a small number of the total species that have yet to be discovered [1-3]. Almost all macro-organisms in marine habitats, e.g., sediment, fish, algae, sponges, corals, ascidians, have been investigated for their content of natural product entities [4,5]. A bioactive compound with unique structures has been isolated and was shown to possess novel anti-inflammatory, antitumor, and antimicrobial properties [6-14]. As interests have turned to marine symbionts, fungi have now begun to be recognized as a likely source of bioactive natural products after having received little attention from natural products chemists [15]. Recently, marine-associated fungi have proved to be a gorgeous source of pharmacologically active natural compounds [14,16-27]. Most of these micro-organisms grow in a unique, extreme, and stressful environment; therefore, they have the ability to yield unusual and unique secondary metabolites [15].

Fungi belonging to the Aspergillus genus are one of the major contributors to the secondary metabolites of fungal origin [14]. Marine-derived isolates of Aspergillus terreus are well known for the production of structurally diverse and biologically active natural products [28,29]. Terrein, a fungal metabolite isolated from $A$. terreus, has been proven to perform diverse biological activities [30-35]. Although terrein has application value in the fields of medicine, cosmetology, and agriculture, large-scale production of pure (+)-terrein cannot be achieved easily. The production of terrein by chemical synthesis is difficult due to its stereoselectivity [36-39] and high-cost chemical reagents [40,41]. In this study, we aimed to use fungal fermentation as a method of low-cost production of terrein in high yield. To our knowledge, the present study describes the highest fermentation production of terrein to date [29,42-49].

The static culture broth and mycelia of $A$. terreus S020 fungus were extracted, and the combined extracts were partitioned by silica gel column chromatography. The pure compound terrein was finally purified using a C18 semi-preparative HPLC column.

As part of our ongoing study to isolate and identify compounds from a marine host [50-54], we cultured and identified fungi from a marine source, assessed bioactive activity against Pseudomona aeruginosa ATCC27853, Bacillus subtilis ATCC6633, Staphylococcus aureus, ATCC25923 and Candida albicansATCC76615, and cytotoxic effects on breast adenocarcinoma (MCF-7), hepatocellular carcinoma (HepG2), and colorectal carcinoma (HCT-116) cells, using crude extracts of the cultured fungal isolates. Further separation, structure determination, and bioactive assessment of the yielded metabolites of selected target strains were performed. A compound, terrein, was separated and purified from the static culture broth of A. terreus strain S020 (Figures S1 and S2). Its chemical structure was elucidated on the basis of HRMS, 1D, and 2D NMR spectroscopic analysie and by comparison with reported data. The isolated compound was tested for its antiproliferative activity.

\section{Experimental Section}

\subsection{Biological Materials}

The deep-sea sediment and the marine sponge specimens used in this study were collected from the Red Sea at Obhur, Jeddah, Saudi Arabia, in January 2016 by SCUBA diving at depths of 17 and $27 \mathrm{~m}$. After collection, the materials were kept at $-25^{\circ} \mathrm{C}$ until investigation.

\subsection{Fungi Isolation}

\subsubsection{Sponge Samples}

Surface sterilization of the sponge samples was performed. The sponge samples were disinfected with 5\% sodium hypochlorite, followed by 70\% ethanol [55]. The inner tissues of sponge materials were cut into pieces of approximately $2 \mathrm{~cm}^{3}$ and homogenized aseptically with sterile, artificial seawater. Three dilutions $(1: 10,1: 100$, and 1:1000) of the resulting homogenate were made with sterile seawater. 


\subsubsection{Sediment Samples}

The deep-sea sediment sample was homogenized aseptically with $15 \mathrm{~mL}$ of sterile water, and the resulting solution was diluted by a serial dilution method.

For fungal cultivation, $90 \mu \mathrm{L}$ of each diluted homogenate was transferred onto plates of each of the following media in triplicate (HiMedia Laboratories, Mumbai, India): Czapek-Dox yeast agar medium (CYE), malt agar medium (ME), and Sabouraud dextrose agar medium (SD). All media were supplemented with an antibiotic $(0.25 \%$ chloramphenicol) and $2 \% \mathrm{NaCl}$. According to Wei's morphological criteria [56], the fungal isolates were identified morphologically on agar plates after 7-14 days incubation at $29^{\circ} \mathrm{C}$. A series of purification and subculture steps were carried out to obtain purified fungal isolates, and photos were taken of each pure isolate (Figure 1).

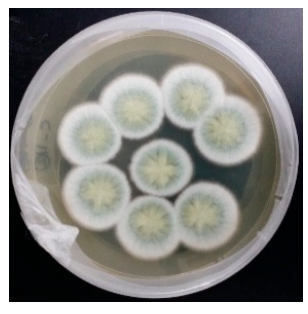

S001

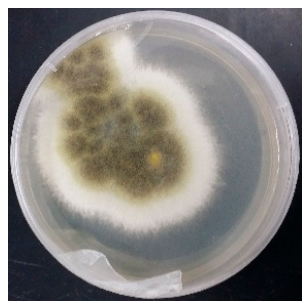

S005

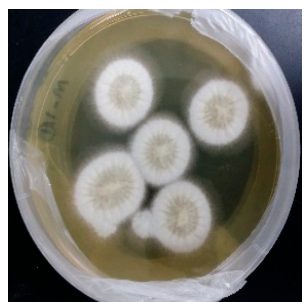

S009

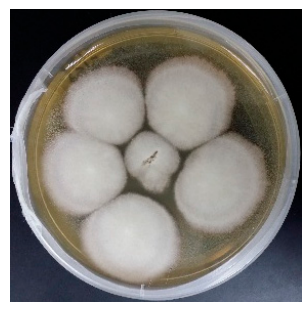

S013

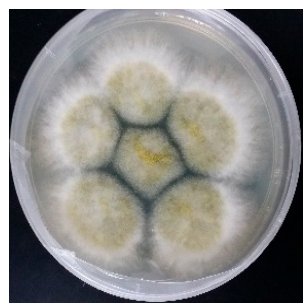

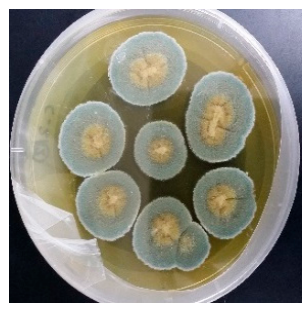

S002

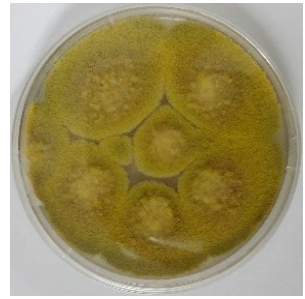

S006

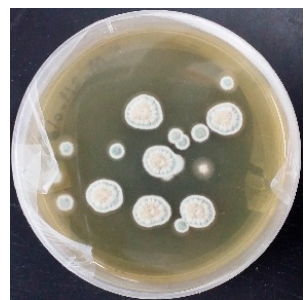

S010

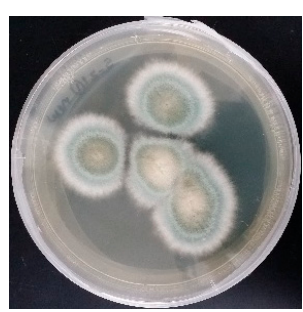

S014

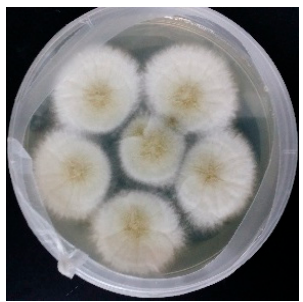

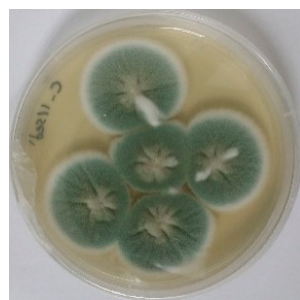

S003

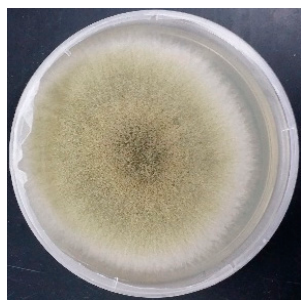

S007

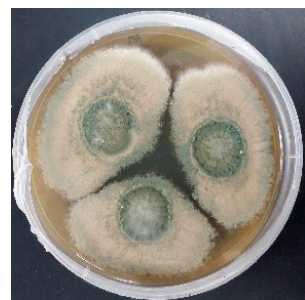

S011

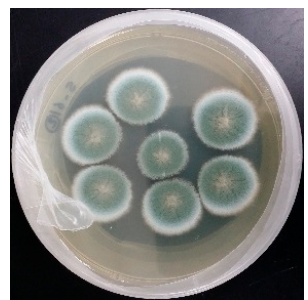

S015

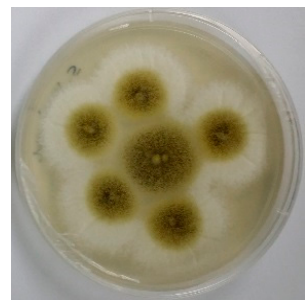

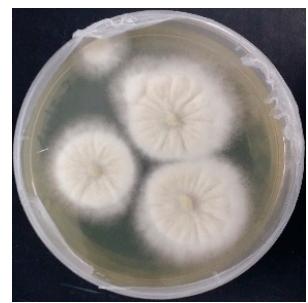

S004

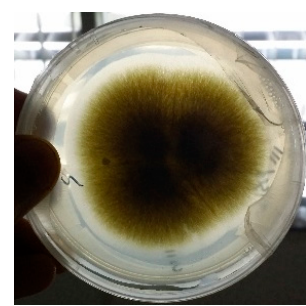

S008

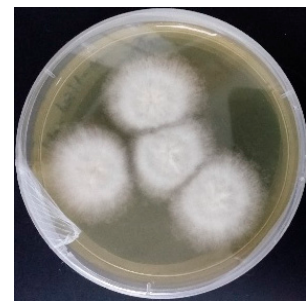

S012

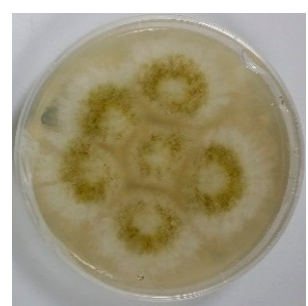

S016

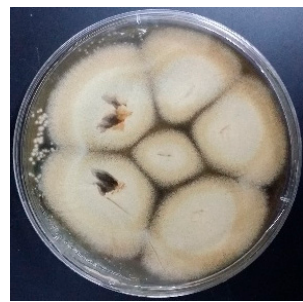

Figure 1. Cont. 


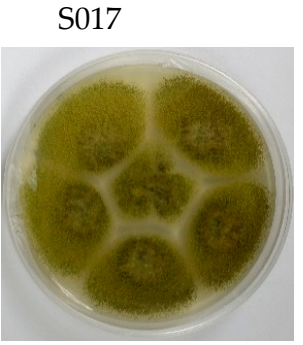

S021

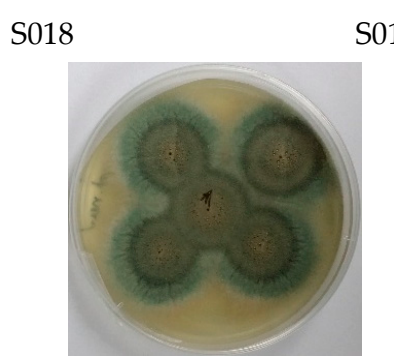

S022
S019

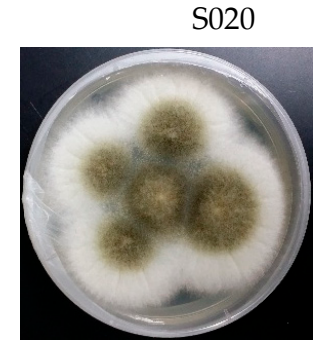

S023

Figure 1. Morphological photos of the 23 derived fungal isolates (S001-S023).

\subsection{DNA Genome Extraction from Pure Subcultured Fungal Isolates}

The distinct, pure fungal isolates described above were subcultured in Sabouraud dextrose liquid medium for 3-7 days at $29^{\circ} \mathrm{C}$. The mycelia were separated by filtration and dried using a freeze dryer. According to the manufacturer's instructions, the fungal DNA extraction of the resulting tissues was performed using the QIAamp DNA Mini Kit (Qiagen, Valencia, CA, USA). The integrity of the extracted DNA was checked and confirmed by gel electrophoresis.

2.4. Internal Transcribed Spacer-rDNA (ITS-rDNA) Fragments Amplification, Sequencing, and Phylogenetic Analysis of Fungal Isolates

Using the primers ITS1 (5'-TCCGTAGGTGAACCTGCG-3') and ITS4 (5'-TCCTCCGCTTATT GATATGC-3') [57], the genomic DNA of the fungal isolates was used as the template to amplify fungal ITS-rDNA fragments. For preliminary identification, the sequences of fungal ITS-rDNA regions were compared with related sequences at the National Center for Biotechnology Information (NCBI) as previously described [58-60].

\subsection{Fermentation and Preparation of Extracts of the Fungal Isolate SO20}

A. terreus strain $\mathrm{S} 020$ was cultured under static conditions at room temperature in $2 \mathrm{~L}$ Erlenmeyer flasks containing $500 \mathrm{~mL}$ of potato dextrose liquid culture medium (PDB). After 40 days of cultivation, $21 \mathrm{~L}$ of whole broth was filtered through cheesecloth to separate the culture broth from the mycelia. The broth was extracted three times with ethyl acetate (EtOAc), while the mycelia were extracted three times with methanol $(\mathrm{MeOH})$. Both EtOAc and $\mathrm{MeOH}$ extracts showed a similar TLC pattern and so were combined and concentrated to generate a crude extract $(17.49 \mathrm{~g})$ for further separation.

\subsection{Isolation and Purification of Terrein}

The total crude extract (17.49 g) of A. terreus strain S020 was subjected to silica gel column chromatography (CC) using gradient elution of $n$-hexane, $\mathrm{CHCl}_{3}$, and $\mathrm{MeOH}$ at a flow rate of about $20 \mathrm{~mL} / \mathrm{min}$. Fractions of $100 \mathrm{~mL}$ were collected and examined by TLC; similar fractions were combined and evaporated under reduced pressure to obtain fractions 1-10. Fraction $5\left(\mathrm{CHCl}_{3}\right.$ fraction, $13.50 \mathrm{~g}$ ) was subjected to silica gel $\mathrm{CC}$ with $\mathrm{CHCl}_{3}-\mathrm{MeOH}$ gradient elution to afford seven further fractions. Of these, the bioactive fractions eluted with $\mathrm{CHCl}_{3}-\mathrm{MeOH}(20: 1)$ were concentrated to yield a terrein precipitate $(9.20 \mathrm{~g}$, purity $85 \%$ ) which was finally purified by HPLC (XDB-C18 Zorbax, $5 \mu \mathrm{m}$, $250 \mathrm{~mm} \times 4.6 \mathrm{~mm}$ ) using $20 \% \mathrm{CH}_{3} \mathrm{CN} / \mathrm{H}_{2} \mathrm{O}$ at a flow rate of $1 \mathrm{~mL} / \mathrm{min}$ and UV detection at $281 \mathrm{~nm}$.

Terrein was characterized as follows: Colorless crystal needles $(10.3 \mathrm{mg}) ; \alpha_{\mathrm{D}}^{25}+151.0(c 0.5, \mathrm{MeOH})$; UV $\left(\lambda_{\max }, \mathrm{MeOH}\right)(\log \varepsilon): 227$ (4.31), 281 (2.51) nm; spectroscopic NMR data: (see Supplementary Materials); ESI-MS: $m / z 155.07[\mathrm{M}+\mathrm{H}]^{+}$; high-resolution electrospray ionization mass spectrometry (HRESIMS): $m / z 155.0698$ (calculated for $\mathrm{C}_{8} \mathrm{H}_{11} \mathrm{O}_{3}[\mathrm{M}+\mathrm{H}]^{+}$, 155.0708). 


\subsection{Biological Activity}

\subsubsection{Preparation of the Extracts of Isolates S001-S023}

The fungal strains S001-S023 were inoculated into $250 \mathrm{~mL}$ Erlenmeyer flasks containing $50 \mathrm{~mL}$ of the corresponding liquid media (Table 1), incubated at $29{ }^{\circ} \mathrm{C}$, and continuously shaken at 150 rounds per minute (rpm) in an orbital shaker for 14 days. After incubation, $50 \mathrm{~mL}$ of EtOAc was added to each flask and left overnight to stop cell growth. The mycelia were separated by filtration, and the filtrate was extracted three times $(3 \times 50 \mathrm{~mL})$ with EtOAc. The organic portion (combined extracts) was evaporated under vacuum, and the residues obtained were washed with water and then taken to dryness to obtain colored crude extracts (broth extract). Other crude extracts (mycelia extract) were obtained by extraction of mycelia with $\mathrm{MeOH}$ and evaporation of the solvent under a vacuum. The resulting EtOAc and $\mathrm{MeOH}$ extracts were lyophilized and stored for biological screening.

Table 1. Antimicrobial activities of isolated fungal strains' (S001-S023) crude extracts of both fermentation broth and mycelia.

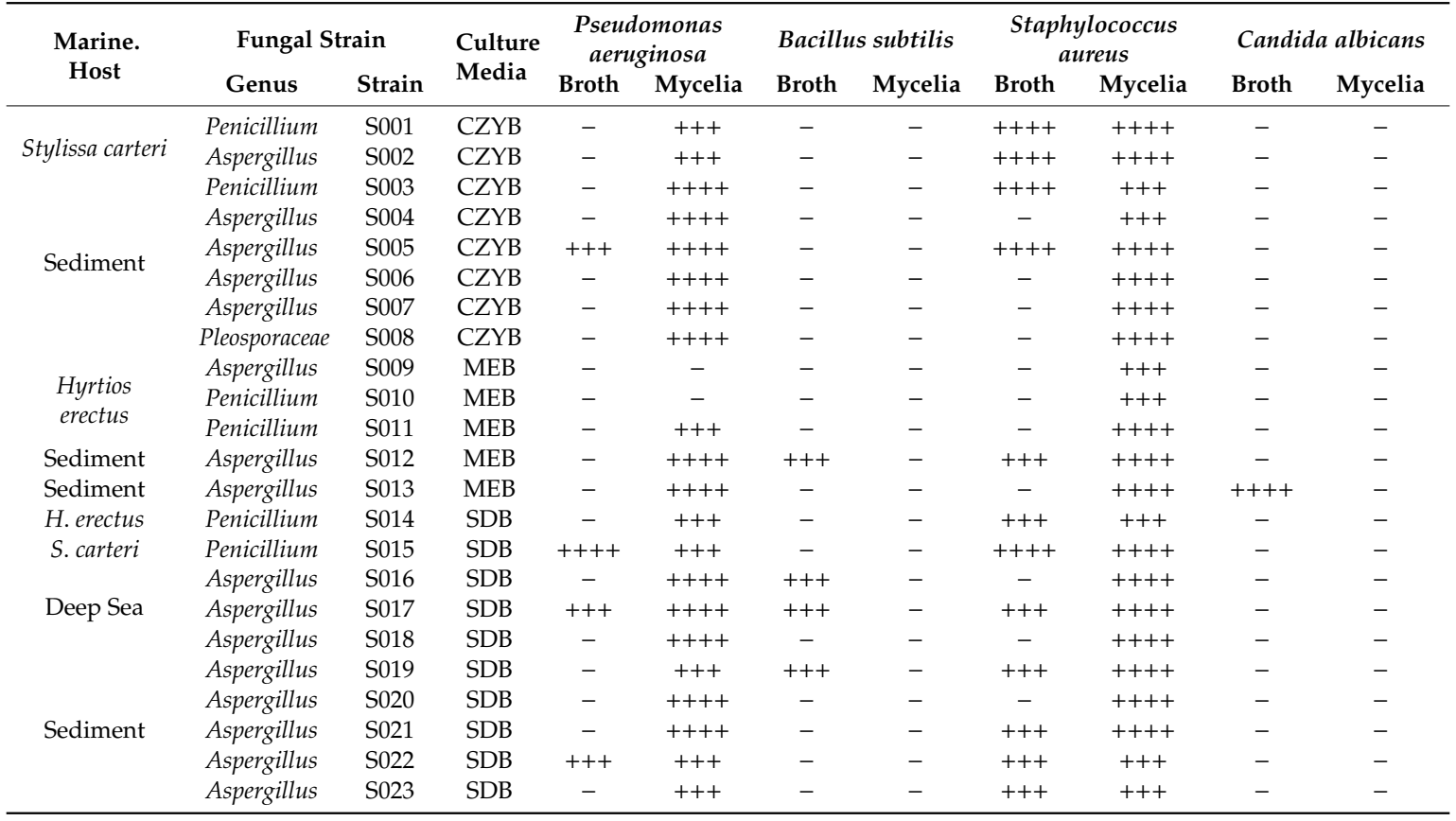

Sabouraud dextrose broth (SDB); malt extract broth (MEB); Czapek-Dox broth (CZYB). Extracts tested at concentrations of $2 \mathrm{mg} / \mathrm{mL}$; inhibition zone in $\mathrm{mm}$ including disc. Inhibition diameters were used to describe the groups of microbial growth inhibition: growth inhibition diameter more than $15 \mathrm{~mm}(++++)$; between 15 and $10 \mathrm{~mm}(+++)$; and less than $7 \mathrm{~mm}(+)$; no inhibition noticed (-).

\subsubsection{Antimicrobial and Cytotoxic Activities of Fungal Extracts of Isolates S001-S023}

The crude extracts of the broth and mycelial biomass were subjected to antimicrobial activity assessment against four pathogenic microorganisms: P. aeruginosa (ATCC27853), B. subtilis (ATCC6633), S. aureus (ATCC25923) and C. albicans (ATCC76615). Assays were performed by placing $50 \mu \mathrm{L}$ of the test extract solution ( $2 \mathrm{mg} / \mathrm{mL}, \mathrm{DMSO}$ ) into each hole on the plates and allowing solutions to stand overnight into an incubator at an appropriate temperature. Activity is indicated by the presence of a clear zone of growth inhibition surrounding the holes. Inhibition zones were measured in $\mathrm{mm}$, and the results are reported in Table 1.

The cytotoxic activity of the test extracts on MCF-7, HCT-116, and HepG2 carcinoma cells was tested using the sulforhodamine B (SRB) assay, as previously described in our studies [54], and the results are presented in Table 2. 
Table 2. In vitro antiproliferative activities $\left(\mathrm{IC}_{50}, \mu \mathrm{g} / \mathrm{mL}\right)$ of isolated fungal strains' (S001-S023) crude extracts of both fermentation broth and mycelia against human carcinoma cells (MCF-7, HCT-116, and HepG2).

\begin{tabular}{|c|c|c|c|c|c|c|c|c|c|}
\hline \multirow{3}{*}{$\begin{array}{c}\text { Marine } \\
\text { Host }\end{array}$} & \multicolumn{2}{|c|}{ Fungal Strain } & \multirow{3}{*}{$\begin{array}{l}\text { Culture } \\
\text { Media }\end{array}$} & \multirow{2}{*}{\multicolumn{4}{|c|}{$\begin{array}{c}\text { Cell Lines } \\
\text { Hepatocellular } \\
\text { HepG2 }\end{array}$}} & \multirow{2}{*}{\multicolumn{2}{|c|}{$\begin{array}{c}\text { Colorectal } \\
\text { HCT-116 }\end{array}$}} \\
\hline & \multirow{2}{*}{ Genus } & \multirow{2}{*}{ Strain } & & & & & & & \\
\hline & & & & Broth & Mycelia & Broth & Mycelia & Broth & Mycelia \\
\hline \multirow{3}{*}{ S. carteri } & Penicillium & S001 & CZYB & 75.44 & $>100$ & 79.26 & $>100$ & $>100$ & 92.60 \\
\hline & Aspergillus & S002 & CZYB & 73.28 & $>100$ & 61.96 & $>100$ & $>100$ & 48.00 \\
\hline & Penicillium & S003 & CZYB & 55.16 & $>100$ & 48.96 & $>100$ & $>100$ & 68.40 \\
\hline \multirow{5}{*}{ Sediment } & Aspergillus & S004 & CZYB & 22.72 & 81.95 & 13.55 & $>100$ & 42.75 & 51.40 \\
\hline & Aspergillus & S005 & CZYB & 70.29 & $>100$ & 60.22 & $>100$ & $>100$ & 70.66 \\
\hline & Aspergillus & S006 & CZYB & 34.27 & 92.15 & 40.20 & $>100$ & 62.20 & $>100$ \\
\hline & Aspergillus & S007 & CZYB & 60.50 & $>100$ & 65.63 & $>100$ & 87.00 & 80.00 \\
\hline & Pleosporaceae & S008 & CZYB & 92.00 & $>100$ & $>100$ & $>100$ & $>100$ & $>100$ \\
\hline & Aspergillus & S009 & MEB & $>100$ & $>100$ & $>100$ & $>100$ & $>100$ & $>100$ \\
\hline \multirow[t]{2}{*}{ H. erectus } & Penicillium & S010 & MEB & 73.60 & $>100$ & $>100$ & $>100$ & $>100$ & $>100$ \\
\hline & Penicillium & S011 & MEB & 57.67 & $>100$ & 83.20 & $>100$ & $>100$ & $>100$ \\
\hline Sediment & Aspergillus & S012 & MEB & $>100$ & 92.00 & 92.00 & $>100$ & $>100$ & 97.00 \\
\hline Sediment & Aspergillus & S013 & MEB & 39.00 & 79.92 & 54.81 & 86.76 & 73.60 & 92.60 \\
\hline H. erectus & Penicillium & S014 & SDB & 79.53 & $>100$ & 92.80 & $>100$ & $>100$ & $>100$ \\
\hline \multirow{2}{*}{ S. carteri } & Penicillium & S015 & SDB & 64.70 & $>100$ & 66.26 & $>100$ & 74.20 & 15.00 \\
\hline & Aspergillus & S016 & SDB & 23.27 & 93.50 & 41.70 & 67.44 & 62.00 & 81.00 \\
\hline \multirow[t]{4}{*}{ Deep Sea } & Aspergillus & S017 & SDB & 42.26 & $>100$ & 54.40 & 99.08 & 53.16 & $>100$ \\
\hline & Aspergillus & S018 & SDB & 60.48 & $>100$ & 97.70 & $>100$ & 90.00 & $>100$ \\
\hline & Aspergillus & S019 & SDB & 51.00 & $>100$ & 86.72 & $>100$ & 49.80 & $>100$ \\
\hline & Aspergillus & S020 & SDB & 44.00 & 81.95 & 57.00 & $>100$ & 47.83 & 67.00 \\
\hline \multirow[t]{4}{*}{ Sediment } & Aspergillus & S021 & SDB & 89.93 & 68.15 & 63.29 & $>100$ & 74.60 & 89.66 \\
\hline & Aspergillus & S022 & SDB & 65.12 & 87.00 & 91.80 & $>100$ & 81.60 & $>100$ \\
\hline & Aspergillus & S023 & SDB & $>100$ & $>100$ & $>100$ & $>100$ & $>100$ & $>100$ \\
\hline & Doxorubicin & & & \multicolumn{2}{|c|}{$0.41 \pm 0.1$} & \multicolumn{2}{|c|}{$0.85 \pm 0.1$} & \multicolumn{2}{|c|}{$0.11 \pm 0.04$} \\
\hline
\end{tabular}

Doxorubicin positive cytotoxic control, presented as the mean \pm SD; $n=3$.

\section{Results and Discussion}

\subsection{Diversity of Culturable Fungal Strains Derived from the Marine Samples}

The cultivation of fungal strains from two marine sponges (Stylissa carteri and Hyrtios erectus) and deep-sea sediment of the Red Sea yielded a total of 36 isolates. Based on morphological traits as well as DNA analysis of the ITS regions [57,61], the redundant strains were excluded, and 23 distinct, pure isolates, were identified (S001-S023; Table 3, Figure 1). The strains from Penicillium spp. and Aspergillus spp. accounted for a large proportion of the total isolates. Twenty-three isolates were identified on the basis of morphological traits at the genus and species levels via genomic DNA extraction and sequencing analysis. 
Table 3. Identification of the isolated fungal strains (S001-S023). The closest relatives to fungal strains according to a BLAST search are presented.

\begin{tabular}{cccccc}
\hline Isolate & $\begin{array}{c}\text { Genus } \\
\text { Identification }\end{array}$ & $\begin{array}{c}\text { Sequence } \\
\text { Length (bp) }\end{array}$ & $\begin{array}{c}\text { Related Strain } \\
\text { (BLAST) }\end{array}$ & Access No. & Similarity (\%) \\
\hline S001 & Penicillium sp. & 522 & $\begin{array}{c}\text { Penicillium } \\
\text { chrysogenum }\end{array}$ & KU556301 & $99 \%$ \\
S002 & Aspergillus sp. & 490 & Aspergillus cristatus & KT151565 & $98 \%$ \\
S003 & Penicillium sp. & 524 & P. chrysogenum & KX266831 & $98 \%$ \\
S004 & Aspergillus sp. & 531 & Aspergillus niger & KJ881377 & $95 \%$ \\
S005 & Aspergillus sp. & 530 & A. niger & KU904480 & $96 \%$ \\
S006 & Aspergillus sp. & 532 & Aspergillus flavus & HQ645940 & $99 \%$ \\
S007 & Aspergillus sp. & 530 & Aspergillus tubingensis & KX015988 & $97 \%$ \\
S008 & Pleosporaceae sp & 505 & Pleosporaceae sp. & KJ443264 & $97 \%$ \\
S009 & Aspergillus sp. & 629 & Aspergillus sp. & HQ023227 & $98 \%$ \\
S010 & Penicillium sp. & 534 & Penicillium polonicum & KF494148 & $99 \%$ \\
S011 & Penicillium sp. & 525 & P. polonicum & KP794074 & $98 \%$ \\
S012 & Aspergillus sp. & 527 & Aspergillus sp. & KX015994 & $97 \%$ \\
S013 & Aspergillus sp. & 502 & Aspergillus foveolatus & KU866615 & $99 \%$ \\
S014 & Penicillium sp. & 519 & P.chrysogenum & KX015998 & $98 \%$ \\
S015 & Penicillium sp. & 526 & P. chrysogenum & KU743900 & $98 \%$ \\
S016 & Aspergillus sp. & 523 & A. flavus & FJ216388 & $98 \%$ \\
S017 & Aspergillus sp. & 529 & A. flavus & KX015986 & $95 \%$ \\
S018 & Aspergillus sp. & 644 & A. niger & KT377250 & $99 \%$ \\
S019 & Aspergillus sp. & 438 & A. niger & LC195003 & $98 \%$ \\
S020 & Aspergillus sp. & 538 & Aspergillus terreus & KX694148 & $98 \%$ \\
S021 & Aspergillus sp. & 330 & Aspergillus sp. & KX000269 & $94 \%$ \\
S022 & Aspergillus sp. & 536 & Aspergillus fumigatus & KU743889 & $98 \%$ \\
S023 & Aspergillus sp. & 531 & Aspergillus sp. & KU842426 & $99 \%$ \\
\hline
\end{tabular}

The phylogenetic tree of fungal strains (Figure 2) represents those fungi that are easily cultivable and could be recovered when culture-dependent techniques are applied [62]. Representative fungal isolates of these strains that have been previously cultured from marine samples include sponges, algae, cnidarians, and sea grasses [63]. The marine invertebrate symbiotic fungi have been reported as a rich source of bioactive secondary metabolites, such as polyketides, with antimicrobial and/or antitumor activities [14,62-64]. Our study revealed that the diversity of symbiotic fungal isolates (Penicillium, 6 strains; Aspergillus, 17 strains; Pleosporaceae, 1 strain) obtained from the marine samples was high. 


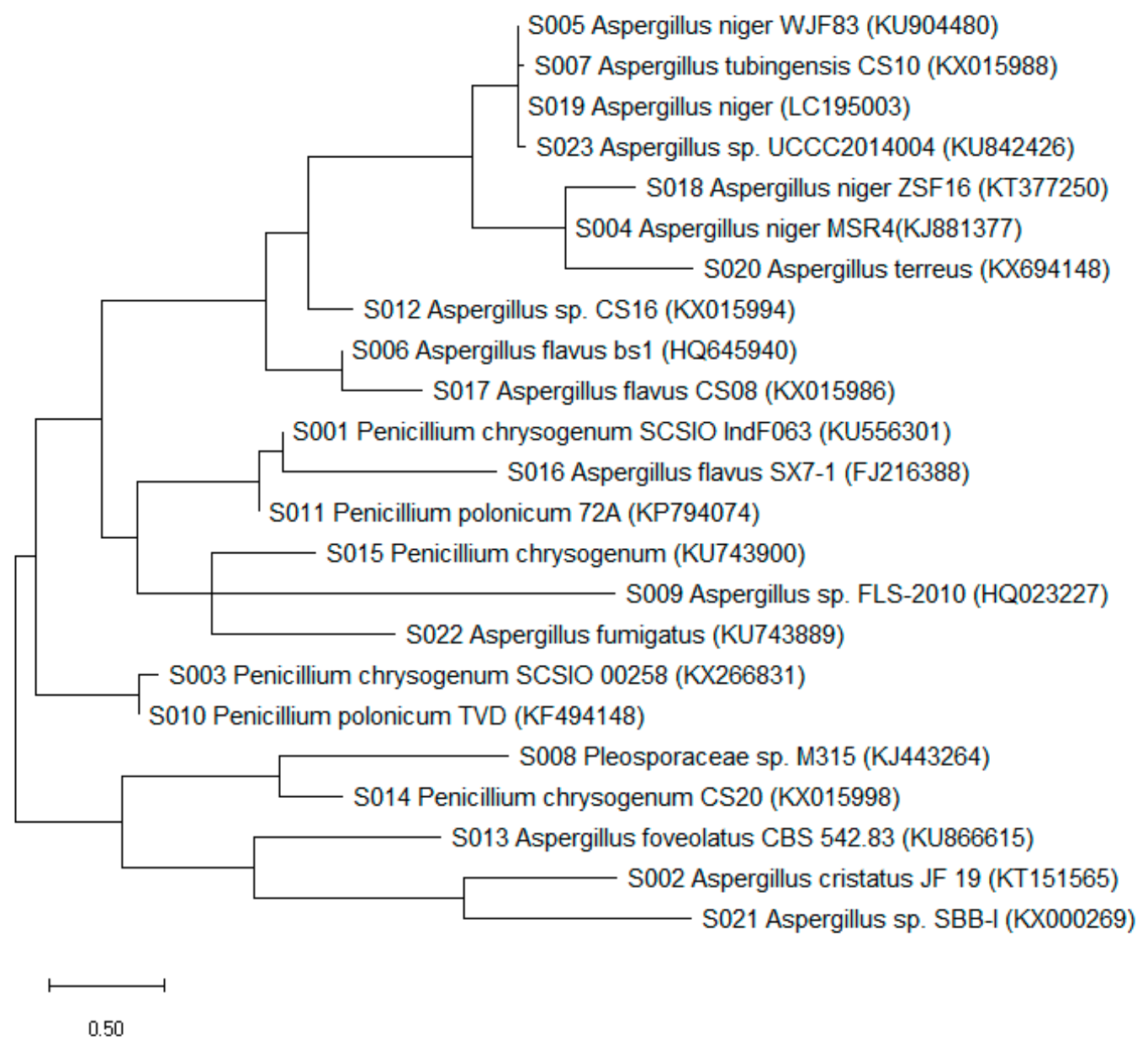

Figure 2. Phylogenetic tree of isolated fungal strains S001-S023.

3.2. Large-Scale Production and Purification of Terrein from A. terreus Strain S020

The culture broth and mycelia of A. terreus strain S020 were extracted using organic solvents, and the combined extracts were fractionated using silica gel column chromatography. The compound terrein was finally purified using a C18 semi-preparative HPLC column.

\subsection{Structure Elucidation of the Isolated Terrein}

Terrein (Figure 3) was isolated and purified as pale yellow crystal needles. The molecular formula, $\mathrm{C}_{8} \mathrm{H}_{10} \mathrm{O}_{3}$, was determined to be $m / z 154.06$ by HRESIMS at $m / z 155.0698[\mathrm{M}+\mathrm{H}]^{+}$and $m / z 177.0529$ $[\mathrm{M}+\mathrm{Na}]^{+}$. Interpretation of NMR and HRMS data (Figures S4-S8) suggested that the compound isolated was terrein, as previously reported [28,42].

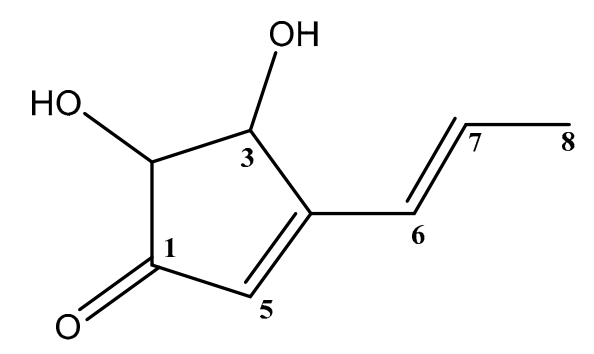

Figure 3. The structure of terrein. 


\subsection{Biological Activities}

\subsubsection{Antimicrobial Activities of the Fungal Extracts}

All 23 fungal isolates were cultured on a small scale, and the crude extracts of their broth and mycelia were tested for antimicrobial activity (against P. aeruginosa ATCC27853, B. subtilis ATCC6633, S. aureus ATCC25923 and C. albicans ATCC76615) using the agar diffusion assay [65]. Fungal isolate extracts displayed different levels of antimicrobial activities against at least one pathogen (Table 1). It is worth pointing out that the extracts of most fungal strains displayed exceptionally high antibacterial activities against $P$. aeruginosa and $S$. aureus (inhibition diameters more than $15 \mathrm{~mm}$ ). Amongst these, the extract of fungal strain S013 exhibited high activity against C. albicans, while other extracts were inactive (Table 1).

From our investigation in this study, we found that extracts of some fungal broths and/or mycelia have antimicrobial effects and that different fungal strains could secrete intracellular and extracellular bioactive metabolic products [66]. Because of the efficacy of these extracts against P. aeruginosa and $S$. aureus, these extracts might have the potential to serve as drug leads to treat a wide variety of diseases. The results of the antimicrobial assay revealed that fungi derived from the marine source isolated in this study might be a prolific source of active compounds, which may hold potential as antibacterial and antifungal natural compounds.

\subsubsection{Antiproliferative Activities of the Fungal Extracts}

All 23 fungal isolates were cultured on a small scale, and the crude extracts of their fungal broth and mycelia were tested for antiproliferative activity against MCF-7, HepG2, and HCT-116 cell lines using the SRB-U assay [67]. The extracts showed variable antiproliferative activity against the cell lines under investigation. Amongst these, extracts of S004, S006, S016, S017, and S020 presented the most promising antiproliferative profile $\left(\mathrm{IC}_{50}\right.$ values of $<50 \mu \mathrm{g} / \mathrm{mL}$ ) (Table 2$)$. The present study revealed the diversity of the antiproliferative potential of marine fungal extracts and, hence, demonstrated their strong potential to produce cytotoxic compounds. Marine fungi and their purified extracts have been shown to be good producers of antiproliferative and cytotoxic compounds. This property could be attributed to different classes of secondary metabolites, as reported previously [20,25-27,68-71].

\subsubsection{Cytotoxic Activity of the Isolated Compound Terrein}

The cytotoxic effect of terrein (Table 4) against HCT-116 and HepG2 cancer cell lines (concentration range 0.01-100 $\mu \mathrm{M}$ ) was assessed using the SRB-U assay [67]. The compound displayed strong antiproliferative activity against the two cell lines under investigation, with $\mathrm{IC}_{50}$ values of $12.13 \mu \mathrm{M}$ and $22.53 \mu \mathrm{M}$ for HCT-116 and HepG2 cells, respectively. Doxorubicin was used as a standard cytotoxic control.

Table 4. In vitro cytotoxic activity $\left(\mathrm{IC}_{50}, \mu \mathrm{M}\right)$ of terrein against human carcinoma cells (HCT-116 and HepG2).

\begin{tabular}{cccc}
\hline Cell Type & Cell Line & Doxorubicin & Terrein \\
\hline Colorectal & HCT-116 & $0.11 \pm 0.04$ & 12.13 \\
Hepatocellular & HepG2 & $0.85 \pm 0.1$ & 22.53 \\
\hline
\end{tabular}

Doxorubicin positive cytotoxic control, presented as the mean $\pm \mathrm{SD} ; \mathrm{n}=3$.

\section{Conclusions}

In conclusion, a total of 23 symbiotic fungi distributed among 3 genera were identified and isolated from marine sponges and sediment collected off Obhur (Saudi Arabia). The biological screening of small-scale cultures of these fungi yielded several target fungal strains which produced secondary bioactive metabolites. Amongst these isolates, the chromatographic separation of the crude 
extract of $A$. terreus strain S020 by silica gel column chromatography led to the isolation of pure crystalline terrain, with a high yield of $537.26 \pm 23.42 \mathrm{~g} / \mathrm{kg}$ dried crude extract; this represents the highest fermentation production of terrein to date. The chemical structure was elucidated on the basis of HRMS, 1D, and 2D NMR spectroscopic analyses, and by comparison with reported data. The isolated compound, terrein, showed strong cytotoxic activity against colorectal carcinoma cells and hepatocellular carcinoma cells, with $\mathrm{IC}_{50}$ values of 12.13 and $22.53 \mu \mathrm{M}$, respectively. Our study contributes to the understanding of fungal diversity and provides the basis for future investigations of these symbionts with respect to identifying and purifying the bioactive leads in these fungal extracts. This study also describes an efficient approach for producing bioactive terrein in a very high yield. Currently, there is great demand for the development of new drugs to combat the emergence of bacterial resistance to traditional antibiotics.

Supplementary Materials: The following are available online at http://www.mdpi.com/2218-273X/9/9/480/s1, Figure S1: HPLC chromatograms of terrein (A) and Aspergillus terreus S020 extract (B), Figure S2: UV-Vis spectra (200-400 nm) of crude extract of A. terreus S020 and terrein, Figure S3: The standard curve for quantifying terrein, Figure S4 (a,b): HRESIMS spectrum of terrein, Figure S5: ESIMS spectrum of terrein, Figure S6: ${ }^{1} \mathrm{H}-\mathrm{NMR}$ spectrum of terrein $\left(\mathrm{CD}_{3} \mathrm{OD}\right)$, Figure S7: ${ }^{13} \mathrm{C}-\mathrm{NMR}$ spectrum of terrein $\left(\mathrm{CD}_{3} \mathrm{OD}\right)$, Figure S8: HMBC spectrum of terrein $\left(\mathrm{CD}_{3} \mathrm{OD}\right)$.

Author Contributions: H.Z.A. and S.S.E. designed the experiments; S.S.E. collected the marine specimen; M.A.E. performed the experiments; Z.A.A. performed the biological activity; S.S.E., H.Z.A., and A.A.B. analyzed the data; and R.F.A.A. and S.S.E. wrote and edited the manuscript.

Funding: This project was funded by the Deanship of Scientific Research (DSR) at King Abdulaziz University, Jeddah, under grant No. G-328-140-38. The authors, therefore, acknowledge with thanks DSR for technical and financial support.

Conflicts of Interest: All contributing authors declare no conflict of interest to disclose, whether financial or of any other nature.

\section{References}

1. Malakoff, D. Extinction on the high seas. Science 1997, 277, 486-488. [CrossRef]

2. Pomponi, S.A. The bioprocess-technological potential of the sea. J. Biotechnol. 1999, 70, 5-13. [CrossRef]

3. Winston, J.E. The systematists' perspective. In Biomedical Importance of Marine Organisms; Fautin, D.G., Ed.; Memoirs of the California Academy of Sciences: San Francisco, CA, USA, 1988; Volume 13, pp. 1-6.

4. Faulkner, D.J. Marine natural products. Nat. Prod. Rep. 2000, 17, 7-55. [CrossRef] [PubMed]

5. Faulkner, D.J. Marine pharmacology. Antonie Van Leeuwenhoek 2000, 77, 135-145. [CrossRef] [PubMed]

6. Bhadury, P.; Wright, P. Exploitation of marine algae: Biogenic compounds for potential antifouling applications. Planta 2004, 219, 561-578. [CrossRef]

7. Donia, M.; Hamann, M.T. Marine natural products and their potential applications as anti-infective agents. Lancet Infect. Dis. 2003, 3, 338-348. [CrossRef]

8. Mayer, A.M.; Hamann, M.T. Marine pharmacology in 2000: Marine compounds with antibacterial, anticoagulant, antifungal, anti-inflammatory, antimalarial, antiplatelet, antituberculosis, and antiviral activities; affecting the cardiovascular, immune, and nervous systems and other miscellaneous mechanisms of action. Mar. Biotechnol. 2004, 6, 37-52.

9. Mehta, A.S.; Gu, B.; Conyers, B.; Ouzounov, S.; Wang, L.; Moriarty, R.M.; Dwek, R.A.; Block, T.M. $\alpha$-Galactosylceramide and Novel Synthetic Glycolipids Directly Induce the Innate Host Defense Pathway and Have Direct Activity against Hepatitis B and C Viruses. Antimicrob. Agents Chemother. 2004, 48, 2085-2090. [CrossRef]

10. Rowley, D.C.; Hansen, M.S.; Rhodes, D.; Sotriffer, C.A.; Ni, H.; McCammon, J.; Bushman, F.D.; Fenical, W. Thalassiolins A-C: New marine-derived inhibitors of HIV cDNA integrase. Bioorganic Med. Chem. 2002, 10, 3619-3625. [CrossRef]

11. Lopes, R.; Schwartsmann, G.; Da Rocha, A.B.; Mattei, J. Marine-derived anticancer agents in clinical trials. Expert Opin. Investig. Drugs 2003, 12, 1367-1383. [CrossRef] 
12. Mayer, A.M.; Rodriguez, A.D.; Berlinck, R.G.; Fusetani, N. Marine pharmacology in 2007-8: Marine compounds with antibacterial, anticoagulant, antifungal, anti-inflammatory, antimalarial, antiprotozoal, antituberculosis, and antiviral activities; affecting the immune and nervous system, and other miscellaneous mechanisms of action. Comp. Biochem. Physiol. Part C: Toxicol. Pharmacol. 2011, 153, 191-222.

13. Kelecom, A. Secondary metabolites from marine microorganisms. Anais da Academia Brasileira de Ciências 2002, 74, 151-170. [CrossRef] [PubMed]

14. Bugni, T.S.; Ireland, C.M. Marine-Derived Fungi: A Chemically and Biologically Diverse Group of Microorganisms. Nat. Prod. Rep. 2004, 35, 143-163. [CrossRef]

15. Bhadury, P.; Mohammad, B.T.; Wright, P.C. The current status of natural products from marine fungi and their potential as anti-infective agents. J. Ind. Microbiol. Biotechnol. 2006, 33, 325-337. [CrossRef] [PubMed]

16. Abdel-Lateff, A.; Klemke, C.; König, G.M.; Wright, A.D. Two New Xanthone Derivatives from the Algicolous Marine Fungus Wardomyces anomalus. J. Nat. Prod. 2003, 66, 706-708. [CrossRef]

17. Klemke, C.; Kehraus, S.; Wright, A.D.; König, G.M. New Secondary Metabolites from the Marine Endophytic Fungus Apiospora montagnei. J. Nat. Prod. 2004, 67, 1058-1063. [CrossRef]

18. Vongvilai, P.; Isaka, M.; Kittakoop, P.; Srikitikulchai, P.; Kongsaeree, P.; Thebtaranonth, Y. Ketene Acetal and Spiroacetal Constituents of the Marine Fungus Aigialus parvus BCC 5311. J. Nat. Prod. 2004, 67, 457-460. [CrossRef]

19. Youssef, D.T.A.; Alahdal, A.M. Cytotoxic and Antimicrobial Compounds from the Marine-Derived Fungus, Penicillium Species. Molecules 2018, 23, 394. [CrossRef]

20. Shaala, L.A.; Youssef, D.T.A. Identification and Bioactivity of Compounds from the Fungus Penicillium sp. CYE-87 Isolated from a Marine Tunicate. Mar. Drugs 2015, 13, 1698-1709. [CrossRef]

21. Yurchenko, A.N.; Smetanina, O.F.; Ivanets, E.V.; Kalinovsky, A.I.; Khudyakova, Y.V.; Kirichuk, N.N.; Popov, R.S.; Bokemeyer, C.; von Amsberg, G.; Chingizova, E.A. Pretrichodermamides D-F from a marine algicolous fungus Penicillium sp. KMM 4672. Mar. Drugs 2016, 14, 122. [CrossRef]

22. Park, H.B.; Kim, Y.-J.; Park, J.-S.; Yang, H.O.; Lee, K.R.; Kwon, H.C. Glionitrin B, a Cancer Invasion Inhibitory Diketopiperazine Produced by Microbial Coculture. J. Nat. Prod. 2011, 74, 2309-2312. [CrossRef] [PubMed]

23. Meng, L.-H.; Zhang, P.; Li, X.-M.; Wang, B.-G. Penicibrocazines A-E, Five New Sulfide Diketopiperazines from the Marine-Derived Endophytic Fungus Penicillium brocae. Mar. Drugs 2015, 13, 276-287. [CrossRef] [PubMed]

24. Li, Y.; Li, X.; Kim, S.-K.; Kang, J.S.; Choi, H.D.; Rho, J.R.; Son, B.W. Golmaenone, a New Diketopiperazine Alkaloid from the Marine-Derived Fungus Aspergillus sp. Chem. Pharm. Bull. 2004, 35, 375-376. [CrossRef] [PubMed]

25. Murshid, S.S.; Badr, J.M.; Youssef, D.T. Penicillosides A and B: new cerebrosides from the marine-derived fungus Penicillium species. Rev. Bras. de Farm. 2016, 26, 29-33. [CrossRef]

26. Asiri, I.A.; Badr, J.M.; Youssef, D.T. Penicillivinacine, antimigratory diketopiperazine alkaloid from the marine-derived fungus Penicillium vinaceum. Phytochem. Lett. 2015, 13, 53-58. [CrossRef]

27. Mourshid, S.S.; Badr, J.M.; Risinger, A.L.; Mooberry, S.L.; Youssef, D.T. Penicilloitins A and B, new antimicrobial fatty acid esters from a marine endophytic Penicillium species. Zeitschrift für Naturforschung C 2016, 71, 387-392. [CrossRef] [PubMed]

28. Raistrick, H.; Smith, G. Studies in the biochemistry of micro-organisms: The metabolic products of Aspergillus terreus Thom. A new mould metabolic product-terrein. Biochem.J. 1935, 29, 606-611.

29. Yin, Y.; Ding, Y.; Feng, G.; Li, J.; Xiao, L.; Karuppiah, V.; Sun, W.; Zhang, F.; Li, Z. Modification of artificial sea water for the mass production of (+)-terrein by Aspergillus terreus strain PF 26 derived from marine sponge Phakellia fusca. Lett. Appl. Microbiol. 2015, 61, 580-587. [CrossRef]

30. Ghisalberti, E.L.; Narbey, M.J.; Rowland, C.Y. Metabolites of Aspergillus terreus antagonistic towards the take-all fungus. J. Nat. Prod. 1990, 53, 520-522. [CrossRef]

31. Arakawa, M.; Someno, T.; Kawada, M.; Ikeda, D. A New Terrein Glucoside, a Novel Inhibitor of Angiogenin Secretion in Tumor Angiogenesis. J. Antibiot. 2008, 61, 442-448. [CrossRef]

32. Park, S.-H.; Kim, D.-S.; Kim, W.-G.; Ryoo, I.-J.; Lee, D.-H.; Huh, C.-H.; Youn, S.W.; Yoo, I.-D.; Park, K.-C. Terrein: A new melanogenesis inhibitor and its mechanism. Cell. Mol. Life Sci. 2004, 61, 2878-2885. [CrossRef]

33. Kim, D.-S.; Cho, H.-J.; Lee, H.-K.; Lee, W.-H.; Park, E.-S.; Youn, S.-W.; Park, K.-C. Terrein, a fungal metabolite, inhibits the epidermal proliferation of skin equivalents. J. Dermatol. Sci. 2007, 46, 65-68. [CrossRef] 
34. Lee, J.-C.; Yu, M.-K.; Lee, R.; Lee, Y.-H.; Jeon, J.-G.; Lee, M.-H.; Jhee, E.-C.; Yoo, I.-D.; Yi, H.-K. Terrein Reduces Pulpal Inflammation in Human Dental Pulp Cells. J. Endod. 2008, 34, 433-437. [CrossRef]

35. Lee, Y.-H.; Lee, N.-H.; Bhattarai, G.; Oh, Y.-T.; Yu, M.-K.; Yoo, I.-D.; Jhee, E.-C.; Yi, H.-K. Enhancement of osteoblast biocompatibility on titanium surface with Terrein treatment. Cell Biochem. Funct. 2010, 28, 678-685. [CrossRef]

36. Auerbach, J.; Weinreb, S.M. Synthesis of terrein, a metabolite of Aspergillus terreus. J. Chem. Soc. Chem. Commun. 1974, 8, 298-299. [CrossRef]

37. Barton, D.H.R.; Hulshof, L.A. Photochemical transformations. Part 35. A simple synthesis of racemic terrein. J. Chem. Soc. Perkin Trans. 1 1977, 9, 1103-1106. [CrossRef]

38. Klunder, A.; Bos, W.; Zwanenburg, B. An efficient stereospecific total synthesis of ( \pm ) terrein. Tetrahedron Lett. 1981, 22, 4557-4560. [CrossRef]

39. Lee, S.; Kim, W.-G.; Kim, E.; Ryoo, I.-J.; Lee, H.K.; Kim, J.N.; Jung, S.-H.; Yoo, I.-D. Synthesis and melanin biosynthesis inhibitory activity of $( \pm)$-terrein produced by Penicillium sp. 20135. Bioorg. Med. Chem. Lett. 2005, 15, 471-473. [CrossRef]

40. Altenbach, H.J.; Holzapfel, W. Synthesis of (+)-Terrein from L-Tartaric Acid. Angew. Chem. Int. Ed. Engl. 1990, 29, 67-68. [CrossRef]

41. Kolb, H.C.; Martin, H.; Hoffmann, R. A total synthesis of racemic and optically active terrein (trans-4, 5-dihydroxy-3-[(E)-1-propenyl]-2-cyclopenten-1-one). Tetrahedron 1990, 1, 237-250. [CrossRef]

42. Kim, W.-G.; Ryoo, I.-J.; Park, S.-H.; Kim, D.-S.; Lee, S.; Park, K.-C.; Yoo, I.-D. Terrein, a melanin biosynthesis inhibitor, from Penicillium sp. 20135. J. Microbiol. Biotechnol. 2005, 15, 891-894.

43. Phattanawasin, P.; Pojchanakom, K.; Sotanaphun, U.; Piyapolrungroj, N.; Zungsontiporn, S. Weed growth inhibitors from Aspergillus fischeri TISTR 3272. Nat. Prod. Res. 2007, 21, 1286-1291. [CrossRef] [PubMed]

44. Demasi, M.; Felicio, A.L.; Pacheco, A.O.; Leite, H.G.; Lima, C.; Andrade, L.H. Studies on terrein as a new class of proteasome inhibitors. J. Braz. Chem. Soc. 2010, 21, 299-305. [CrossRef]

45. Wang, Y.; Zheng, J.; Liu, P.; Wang, W.; Zhu, W. Three New Compounds from Aspergillus terreus PT06-2 Grown in a High Salt Medium. Mar. Drugs 2011, 9, 1368-1378. [CrossRef] [PubMed]

46. Xu, B.; Yin, Y.; Zhang, F.; Li, Z.; Wang, L. Operating conditions optimization for (+)-terrein production in a stirred bioreactor by Aspergillus terreus strain PF-26 from marine sponge Phakellia fusca. Bioprocess Biosyst. Eng. 2012, 35, 1651-1655. [CrossRef] [PubMed]

47. Yin, Y.; Gao, Q.; Zhang, F.; Li, Z. Medium optimization for the high yield production of single (+)-terrein by Aspergillus terreus strain PF26 derived from marine sponge Phakellia fusca. Process Biochem. 2012, 47, 887-891. [CrossRef]

48. Xiao, L.; Yin, Y.; Sun, W.; Zhang, F.; Li, Z. Enhanced production of (+)-terrein by Aspergillus terreus strain PF26 with epigenetic modifier suberoylanilide hydroxamic acid. Process Biochem. 2013, 48, 1635-1639. [CrossRef]

49. Yin, Y.; Xu, B.; Li, Z.; Zhang, B. Enhanced production of (+)-terrein in fed-batch cultivation of Aspergillus terreus strain PF26 with sodium citrate. World J. Microbiol. Biotechnol. 2013, 29, 441-446. [CrossRef]

50. Elhady, S.S.; El-Halawany, A.M.; Alahdal, A.M.; Hassanean, H.A.; Ahmed, S.A. A New Bioactive Metabolite Isolated from the Red Sea Marine Sponge Hyrtios erectus. Molecules 2016, 21, 82. [CrossRef]

51. Elhady, S.S.; Al-Abd, A.M.; El-Halawany, A.M.; Alahdal, A.M.; Hassanean, H.A.; Ahmed, S.A. Antiproliferative Scalarane-Based Metabolites from the Red Sea Sponge Hyrtios erectus. Mar. Drugs 2016, 14, 130. [CrossRef]

52. Alahdal, A.M.; Shaala, L.A.; Noor, A.O.; Elfaky, M.A.; Elhady, S.S.; Almohammadi, A.; Bagalagel, A.; Lashkar, M.O.; Almasri, D.M.; Youssef, D. Evaluation of the antiproliferative and cytotoxic activities of marine invertebrates-derived fungi. Pak. J. Pharm. Sci. 2017, 30, 1001-1006. [PubMed]

53. Bagalagel, A.A.; Bogari, H.A.; Ahmed, S.A.; Diri, R.M.; Elhady, S.S. New Bromoindole Alkaloid Isolated from the Marine Sponge Hyrtios erectus. Heterocycles 2018, 96, 749-756.

54. Alahdal, A.M.; Asfour, H.Z.; Ahmed, S.A.; Noor, A.O.; Al-Abd, A.M.; Elfaky, M.A.; Elhady, S.S. Anti-Helicobacter, Antitubercular and Cytotoxic Activities of Scalaranes from the Red Sea Sponge Hyrtios erectus. Molecules 2018, 23, 978. [CrossRef] [PubMed]

55. Li, Q.; Wang, G. Diversity of fungal isolates from three Hawaiian marine sponges. Microbiol. Res. 2009, 164, 233-241. [CrossRef] [PubMed]

56. Wei, J. Fungal Identification Manual; Shanghai Science and Technology Press: Shanghai, China, $1979 ;$ p. 496. 
57. White, T.; Bruns, T.; Lee, S.; Taylor, J. Amplification and direct sequencing of fungal ribosomal RNA genes for phylogenetics. PCR Protocols 1990, 18, 315-322.

58. Thompson, J.D.; Gibson, T.J.; Plewniak, F.; Jeanmougin, F.; Higgins, D.G. The CLUSTAL_X windows interface: Flexible strategies for multiple sequence alignment aided by quality analysis tools. Nucleic Acids Res. 1997, 25, 4876-4882. [CrossRef] [PubMed]

59. Hall, T.A. BioEdit: A user-friendly biological sequence alignment editor and analysis program for Windows 95/98/NT. Nucleic Acids Symp. Ser. 1999, 41, 95-98.

60. Tamura, K.; Peterson, D.; Peterson, N.; Stecher, G.; Nei, M.; Kumar, S. MEGA5: Molecular Evolutionary Genetics Analysis Using Maximum Likelihood, Evolutionary Distance, and Maximum Parsimony Methods. Mol. Boil. Evol. 2011, 28, 2731-2739. [CrossRef]

61. Schoch, C.L.; Seifert, K.A.; Huhndorf, S.; Robert, V.; Spouge, J.L.; Levesque, C.A.; Chen, W.; Consortium, F.B. Nuclear ribosomal internal transcribed spacer (ITS) region as a universal DNA barcode marker for Fungi. Proc. Natl. Acad. Sci. USA 2012, 109, 6241-6246. [CrossRef]

62. Baker, P.W.; Kennedy, J.; Dobson, A.D.; Marchesi, J.R. Phylogenetic diversity and antimicrobial activities of fungi associated with Haliclona simulans isolated from Irish coastal waters. Mar. Biotechnol. 2009, 11, 540-547. [CrossRef]

63. Da Silva, M.; Passarini, M.R.Z.; Bonugli, R.C.; Sette, L.D. Cnidarian-derived filamentous fungi from Brazil: Isolation, characterisation and RBBR decolourisation screening. Environ. Technol. 2008, 29, 1331-1339. [CrossRef]

64. Höller, U.; Wright, A.D.; Matthee, G.F.; König, G.M.; Draeger, S.; Aust, H.-J.; Schulz, B. Fungi from marine sponges: Diversity, biological activity and secondary metabolites. Mycol. Res. 2000, 104, 1354-1365. [CrossRef]

65. Inderlied, C.; Salfinger, M. Antimicrobial Agents and Susceptibility Tests: Mycobacteria. Manual of Clinical Microbiology, 6th ed.; ASM Press: Washington, DC, USA, 1995; pp. 1385-1404.

66. Konings, W.N.; Poolman, B.; Driessen, A.J. Can the excretion of metabolites by bacteria be manipulated? FEMS Microbiol. Lett. 1992, 88, 93-108. [CrossRef]

67. Skehan, P.; Scudiero, D.; Vistica, D.; Bokesch, H.; Kenney, S.; Storeng, R.; Monks, A.; McMahon, J.; Warren, J.T.; Boyd, M.R. New Colorimetric Cytotoxicity Assay for Anticancer-Drug Screening. J. Natl. Cancer Inst. 1990, 82, 1107-1112. [CrossRef]

68. Evidente, A.; Kornienko, A.; Lefranc, F.; Cimmino, A.; Dasari, R.; Evidente, M.; Mathieu, V.; Kiss, R. Sesterterpenoids with Anticancer Activity. Curr. Med. Chem. 2015, 22, 3502-3522. [CrossRef]

69. Gomes, N.G.M.; Lefranc, F.; Kijjoa, A.; Kiss, R. Can Some Marine-Derived Fungal Metabolites Become Actual Anticancer Agents? Mar. Drugs 2015, 13, 3950-3991. [CrossRef]

70. Jin, L.; Quan, C.; Hou, X.; Fan, S. Potential Pharmacological Resources: Natural Bioactive Compounds from Marine-Derived Fungi. Mar. Drugs 2016, 14, 76. [CrossRef]

71. Imhoff, J.F. Natural Products from Marine Fungi-Still an Underrepresented Resource. Mar. Drugs 2016, 14, 19. [CrossRef]

(C) 2019 by the authors. Licensee MDPI, Basel, Switzerland. This article is an open access article distributed under the terms and conditions of the Creative Commons Attribution (CC BY) license (http://creativecommons.org/licenses/by/4.0/). 